\title{
THE THIRD REPUBLIC AS MANAGER: LABOR POLICY IN THE NAVAL SHIPYARDS, 1892-1920*
}

Recently there has been great interest in the re-organization of work and its effects on labor relations during the last decades of the nineteenth century and the first decades of the twentieth century, particularly in the metalworking and machine industries. ${ }^{1}$ Studies of this issue have generally been framed in terms of technological advances in the steel industry in the second half of the nineteenth century, the exigencies of the market during and after the Great Depression of the late nineteenth century, and the efforts of skilled labor to defend its position on the shopfloor. In France and elsewhere the importance of national and international arms sales before 1914 made the armaments industry one of the main arenas of these developments. Until mid-century the defense industry and the business of defense had been under state control in France. Largely for economic reasons, however, the Third Republic turned over increasing amounts of defense contracting, especially in shipbuilding, to private industry. ${ }^{2}$ The Etablissements Schneider at Le Creusot, the Compagnie des Aciéries de la Marine at Saint-Chamond and other large private firms established themselves as profitable arms manufacturers. National and foreign government contracts for weaponry encouraged these companies to make large capital invest-

* I would like to thank Herrick Chapman for his helpful comments on an earlier draft of this article.

1 For the United States, see H. Braverman, Labor and Monopoly Capital. The Degradation of Work in the Twentieth Century (New York, 1974); D. Clawson, Bureaucracy and the Labor Process. The Transformation of U.S. Industry, 1860-1920 (New York, 1980); D. Montgomery, Workers' Control in America (Cambridge, 1979); D. Nelson, Managers and Workers. Origins of the New Factory System in the United States 18801920 (Madison, 1975). For an interpretation of this work in the French context, see P. Fridenson, "France, Etats-Unis: Genèse de l'usine nouvelle", in: Le Soldat du travail, ed. by L. Murard and P. Zylberman (Paris, 1978), pp. 375-88.

2 F. Crouzet, "Recherches sur la production d'armements en France (1815-1913)", in: Revue Historique, CCLII (1974), pp. 45-84; "Remarques sur l'industrie des armements en France (du milieu du XIXe siècle à 1914)", ibid., pp. 409-22. 
ments, to rationalize work to permit greater managerial control, and to develop authoritarian paternalist systems of labor management. ${ }^{3}$

If constructing war machinery was a profitable business, maintaining preparedness for war - the ultimate mission of the military and of its industrial branches, including the naval shipyards - was not. In such a situation, how was the Third Republic to organize work in the naval shipyards? This issue was not simply one of deciding what size labor-force was necessary or what it should do - although these were constant subjects of debate -, but how this labor should be managed. At the turn of the century the shipyards at Brest, Lorient, Rochefort, Cherbourg and Toulon "forment certainement le groupe le plus important des établissements s'occupant de travaux mécaniques et de construction métallique en France." 4 In the decades before 1914 they employed between twenty and twenty-five thousand workers. By its very nature the problems which the navy faced in running the shipyards differed from those in the private armaments industry. Was a larger workforce than could be productively employed during normal conditions necessary to assure that emergency work would be done quickly in periods of crisis? How should administrators deal with a situation where discipline and productivity were not as closely tied as in a private firm dependent for its survival on success in the marketplace?

The answers to these questions are to be found not by making general extrapolations from the exigencies of the work process, but from analyzing the parameters set by the political economy of the particular enterprise in question. The present article begins with a brief survey of the history of labor relations in the naval shipyards before the transition from sailing to steam ships. This is followed by an analysis of the ways in which the administration of the naval shipyards sought to develop a new form of labor management suitable to the changing role of the naval shipyards in the decades before and after the turn of the century.

Until the mid nineteenth century the French navy was composed of wooden sailing ships. Two characteristics differentiated naval shipbuilding during this period from that of the era of steam-powered iron and steel vessels which followed. The carpenters and blacksmiths needed to con-

${ }^{3}$ For Le Creusot, see C. Devillers and B. Huet, Le Creusot. Naissance et développement d'une ville industrielle 1782-1914 (Seyssel, 1981). For Saint-Chamond, see M. P. Hanagan, The Logic of Solidarity. Artisans and Industrial Workers in Three French Towns 1871-1914 (Urbana, 1980), pp. 129-35.

4 Directeur des Constructions navales (hereafter DCN) Rochefort, 27 June 1902, Archives de la Marine, Vincennes, (hereafter AM), 6 DD 1519 7904. The navy also maintained foundries at Indret and Guérigny. 
struct sailing ships were the same workers required to repair them. Much of this labor-force was obtained through conscription. Second, only the state could afford to maintain the large supplies of aged wood necessary for the construction and repair of a fleet of sailing ships. This changed with the switch to steam-powered metal ships in the second half of the century. The labor needed to construct and repair these new ships was not the same, as it had been earlier. The shipyards had to abandon conscription and turn to the open labor market for these new types of workers. Still, turn-of-the-century shipyards frequently lacked sufficient specialists for one aspect of construction or repairs and had too many for another. As far as materials went, unlike aged wood, large quantities of the iron and steel needed for steam ships were readily available to private industry.

Development of the naval shipyards during the Third Republic was shaped by parliament's desire to maintain employment levels while restricting capital investment. The government began to contract out some shipbuilding to private metallurgical firms, while reserving assemblage and repairs for the shipyards. This was one element in a general de-nationalization and internationalization of the arms industry in the decades before World War I, most evident in the Republic's decision in 1885 to allow French armaments manufacturers to sell weapons to foreign countries. ${ }^{5}$

Naval shipyard administrators found that military models of discipline, which had been developed for conscript labor, were ill-suited to a skilled labor-force recruited from the open market. Furthermore, the transfer of large elements of shipbuilding to private industry and the consequent irregularity of work, both in terms of quantity and nature, buttressed the animus against piece-rates deep in the naval-shipyard workers' culture. Systems of labor management applicable to assemblage were often impractical to remunerate workers who did repairs. Naval-shipyard managers turned to various institutional means of involving workers' representatives in order to create a new basis of authority in the shipyards, one which had implications for French labor as a whole.

\section{From sail to steam}

Naval shipyards as they existed in the Third Republic were direct descendants of Louis XIV's France. ${ }^{6}$ As part of the re-organization of France's

5 See W. McNeill, The Pursuit of Power. Technology, Armed Force, and Society since A.D. 1000 (Chicago, 1982), pp. 262-306.

6 On the history of French naval shipyards, see G. Dagnaud, La Condition des ouvriers des arsenaux de la Marine (Paris, 1904); J. Royer-Collard, Les Ouvriers des arsenaux (Paris, 1905); Mathias, Nos Directions de travaux. Etude pratique sur le fonctionnement du service administratif dans les arsenaux maritimes (Lorient, 1909); L. Ribeyrol, De la 
military, Colbert had established naval conscription (inscription maritime) in coastal areas. Conscription applied not only to sailors, but to the carpenters, caulkers and sailmakers required by the shipyards as well. Some of these workers stayed on voluntarily and their sons apprenticed in the shipyards. The permanent workers formed a stable core and at retirement were placed on half-pay. All workers were subject to military discipline. During the Revolution, the state gave the shipyard workers the right to elect their masters, and established regulations governing hiring and advancement. ${ }^{7}$ Napoleon did away with these reforms and thoroughly militarized the naval shipyards, requiring workers to wear uniforms and to live in military barracks unless they had wives in town.

Over the course of the nineteenth century technological and political developments ended the efforts of Napoleon and his successors to turn the shipyards into usines militarisées. Few residents of seacoast towns had the skills required to build and repair the steam-powered vessels which replaced wooden sailing ships after mid-century. Naval shipyards were forced to hire free, non-conscript workers to do this work. The conscripts, untrained in metal working, were an unnecessary expense. ${ }^{8}$ In 1864 the Second Empire rectified the situation by abolishing shipyard conscription; in the future all shipyard workers would be freely recruited by regular hiring procedures or by apprenticeship. The worker was given a promise of permanent employment (immatriculation) unless he committed a grievous breach of discipline, or became incapacitated due to injury or illness. Workers who retired with twenty-five years of service received a military pension: two-thirds of their highest pay. In 1892 recruitment changed slightly with the introduction of ouvriers temporaires. After three years the shipyard decided whether or not to give these workers the status of immatricules. While this allowed the shipyards to eliminate refractory and physically unfit workers, it did not really permit the navy to vary the size of

Condition économique et juridique du personnel ouvrier des Arsenaux et Etablissements hors ports de la Marine (Paris, 1909); A. Dupont, Les Arsenaux de la Marine de 1689 à 1910. Leur organisation administrative (Paris, 1913); J. Fonlupt-Espéraber, Etude historique et critique sur le recrutement et le salaire des ouvriers des arsenaux (Paris, 1913); L. Krebs, Les Arsenaux et établissements de la marine. Condition, salaire et rendement du travail (Paris, 1913); S. Travers, Le Statut du personnel ouvrier et le problème de la main-d'oeuvre dans les arsenaux de la marine française (Paris, 1935); P. Appert, Les Améliorations récentes dans la condition sociale du personnel ouvrier des arsenaux de la marine (Aix-en-Provence, 1939).

7 N. Hampson, "Les Ouvriers des arsenaux de la marine au cours de la Révolution française (1789-1794)", in: Revue d'Histoire Economique et Sociale, XXXIX (1961), pp. 287-329, 442-73.

${ }_{8}$ A. Wilhelm, "Note au sujet de la condition des ouvriers des arsenaux et établissements de la Marine", 9 July 1891, AM 6 DD 1499. 
the industrial labor-force according to its needs. The shipyards were located in non-industrial areas. The navy could ill afford to lay off workers with specialized skills for even a short time for fear that they would leave to work elsewhere. ${ }^{9}$

Neither these changes in recruitment nor the establishment of the Third Republic in 1870 affected the military nature of the shipyards. Each naval port remained under the direct control of a naval officer, the maritime prefect, and naval officers continued to monopolize the upper echelons of management in the shipyards. Yet these naval officers were not free to set policy.

Les textes s'imposent à eux comme aux ouvriers et avec la même puissance; alors que le chef d'une entreprise privée peut à son gré organiser son usine et en discuter avec son personnel, l'Ingénieur qui est à la tête d'une direction ou d'un service dans un arsenal, peut seulement appliquer les ordres émanant du Ministre, de la manière la plus conforme aux necessités particulières de son établissement, mais n'a jamais la possibilité de modifier un règlement. Sans doute pourra-t-il écouter les demandes de ses ouvriers et en apprécier le bien-fondé, son seul pouvoir est de les transmettre au Ministre ou à son représentant qui pourra ou non les prendre en considération. ${ }^{10}$

The Minister's right to formulate all aspects of naval policy, including labor relations, would form the basis of social policy in the shipyards during the Third Republic. ${ }^{11}$

Proponents of reforms in the shipyards often touted them as models for private firms. The Service de Santé established by the Minister of the Navy in 1900 editorialized: "Patron [l'Etat] n'est pas dans les conditions ordinaires, et il doit, aux patrons de l'industrie, l'exemple de la bonté, de la sollicitude envers ses ouvriers." 12 The Radical deputy Louis Martin argued before the Chamber in 1905 that the legitimacy of the state's role as mediator in labor conflicts in the private sector was at stake in its treatment of shipyard workers.

L'Etat doit être le modèle de tous les patrons. Il a, lui, des facilités spéciales; il se trouve dans une situation tout à fait particulière et peut faire ce que ne peuvent faire tous les patrons industriels; il doit par conséquent, donner le bon exemple.

${ }^{9}$ Inspecteur général, "Rapport rélatif au port de Cherbourg”, 22-26 July 1895, AM 6 DD 1310.

10 Appert, Les Améliorations récentes, op. cit., pp. 18-19.

11 For the French navy before World War I, see T. Ropp, "The Development of a Modern Navy: French Naval Policy, 1871-1914" (Ph.D., Harvard University, 1937), and J. Walser, "France's Search for a Battlefleet: French Naval Policy (1898-1914)" (Ph.D., University of North Carolina, 1976).

12 "Rapport du Service de Santé établi en exécution de la Dépêche Ministérielle du 4 décembre 1900", AM 6 DD 15267934. 
Combien de fois n'arrive-t-il pas que dans les conflits entre le travail et le capital l'Etat est pris pour arbitre en raison de la neutralité qui lui appartient, qui est sienne. Eh bien! Je me demande quelle sera l'autorité morale de l'Etat dans ces arbitrages s'il est lui-même, je ne dis pas le plus dur, mais le plus avare de tous les patrons. ${ }^{13}$

The unions re-iterated this line of argument. In criticizing task-rates (travail à la tâche) P. Frès, leader of the Syndicat des Travailleurs des Ports et Etablissements Maritimes, wrote: "Il est interdit à l'Etat, patron républicain, de spéculer sur la force d'endurance des ouvriers." $1+4$

\section{The remuneration of labor}

The debate over labor in the naval shipyards before the First World War concerned the relationship of low wages and job security to productivity, discipline and morale. ${ }^{15}$ This question was not unique to the naval shipyards, of course. What gave the issue particular resonance in the shipyards was the Third Republic's search for a labor policy which would combine justice, fraternity, and a respect for individual initiative. For ideological and economic reasons the trend in private industry during the nineteenth century had been toward the payment of piece-rates or taskrates whenever possible. ${ }^{16}$ These systems of payment promised a certain labor cost with minimum supervision and claimed to recognize the liberty of the worker to set the pace of his work. Yet until the 1890's, naval-shipyard workers were generally paid a daily wage based on their rank and their seniority. The wage scale was clearly lower than that paid workers in comparable jobs in the private sector in France or in foreign shipyards, and remained so until the war; workers looked forward to their pension as compensation. ${ }^{17} \mathrm{G}$. Dagnaud, chef de bureau at the Ministry of the Navy, voiced the typical comment that in the absence of other large employers in the port towns there was among the shipyard workers "une sorte de tranquillité et de sérénité dans la misère qu'on chercherait en vain ailleurs".

13 Journal Officiel de la Chambre des Députés, 22 February 1905, p. 569.

${ }^{14}$ L'Emancipateur (Toulon), 16-30 June 1907, p. 3. L'Emancipateur was the journal of the Syndicat des Travailleurs des Ports et Etablissements Maritimes.

${ }_{15}$ This was related to the debate between two groups of naval strategists, the Jeune Ecole and the Vieille Ecole, as to the type of navy France should build. On this controversy see Walser, "France's Search for a Battlefleet", op. cit.

${ }^{16}$ B. Mottez, Systèmes de salaire et politiques patronales (Paris, 1966).

17 "The wages of free labor [in the French naval shipyards] are sufficiently low to accomplish a great deal of work at an outlay which in [the United States] would be regarded as insignificant." Ph. Hichborn, Report on European Dockyards (prepared for the US Navy) (Washington, 1886), p. 27. 
Il est tellement sûr d'avoir le même salaire - ou à peu près - demain et jusqu'à sa retraite, qu'il pleuve, qu'il gèle, qu'il y ait du travail ou qu'il n'y en ait pas, qu'il laisse couler les jours dans une sorte de quiétude fataliste qui est touchante pour ceux qui savent ce qu'elle cache de privations. La vertu à laquelle il est le moins propre, c'est l'initiative; il n'y en a guère plus dans sa vie que dans son travail. Il pourrait parfois gagner le double dans un chantier de l'industrie, mais il ne tentera rien de crainte de "risquer son pain". Il a horreur de l'incertitude et quand on lui dit qu'il est malheureux, il répond naïvement, "Oui, mais c'est sûr."18

Many republican officials envisaged task-rates as a way to promote the moral virtues of independence and initiative among shipyard workers. However, the limited introduction in 1892 of primes horaires, or Halsay rates, in which the worker and the shipyard shared the money saved by faster work, revealed several problems. The irregularity of work at the shipyards and the promise of lifetime employment to ouvriers immatriculés reduced the incentive for either workers or management to rush production. The director of naval construction at Lorient reported in 1893 that the primes horaires increased absenteeism: "La paye touchée par l'ouvrier étant variable d'une quinzaine à l'autre, la famille n'a plus de contrôle comme anciennement." ${ }^{19}$ In any case the wide variety of work carried out in the shipyards, both in construction and repair, made the setting of rates difficult. Relatively few jobs could be easily measured to determine the base production level necessary to calculate production bonuses. The one exception was the operation of certain machines by unskilled workers. As a result, some unskilled machine operators could make more than skilled workers performing a variety of difficult, though non-quantifiable, tasks at a day-rate. One observer wrote:

Le cas est assez fréquent pour que les ingénieurs, désireux de s'opposer au déclassement des ouvriers, sans les décourager, aient été amenés à étendre la rémunération à la tâche à certains travaux qui ne le supportent guère. "Les ingénieurs", nous écrit un de nos correspondants, "sont toujours à la recherche de nouveaux tarifs, d'unités de mesure pour les travaux les moins mesurables." 20

The primes horaires were employed most and were most applauded by the directors at assemblage and construction centers, Brest and Lorient,

18 Dagnaud, La Condition des ouvriers, op. cit., pp. 50-51.

19 DCN Lorient, 1893, AM 6 DD 1309 5915. Payment by production undermined a form of social control exercised by the family.

20 Fonlupt-Espéraber, Etude historique et critique, op.cit., pp. 122-23 (quoted); DCN Rochefort, "Note sur les primes à la production et le travail à la tâche", 13 July 1901, and Laubeuf, ingénieur en chef (Toulon), "Note au sujet du travail à la prime", 3 December 1904, both AM 6 DD 15197904. 
and were used least and with the least enthusiasm at the shipyards devoted primarily to repairs, Toulon and Cherbourg. The "profit" created by men working at primes horaires was split between the workers and the shipyard at a proportion of anywhere from less than two to one at Brest, where over fifty per cent of the workers were on primes horaires in the late 'nineties, to up to eight to one at Toulon in 1897, where only one in eight workers participated. ${ }^{21}$ While some workers claimed that task-rates reduced the quality of work, certain directors saw this as part of the change from the artisanal mentality that had gone into the construction of wooden ships to the new habits required by more modern methods of shipbuilding.

Il est certain qu'on exigeait [des ouvriers] autrefois un fini qui faisait de nos coques, comme celle du "Dupuy de Lôme" par exemple, une sorte de chaudronnerie d'art, beaucoup trop coûteuse, ce qui n'était nullement justifié par un accroissement de solidité correspondant. Aussi avais-je depuis quelque temps renoncé à demander une pareille perfection. ${ }^{22}$

Rate setting encouraged workers to consider only the level of production and to leave the question of standards to their supervisors.

Payment by production required a large, well-trained staff to set rates, to supervise the finished product, to handle the additional accounting, and to prevent workers paid by the day from helping those paid by the job. ${ }^{23}$ The Third Republic took several steps to give foremen an independent status. In 1879 the Minister of the Navy issued a decree that definitively separated foremen from workers. "Les contremaîtres et chefs contremaîtres [. . .] bénéficiaient d'une forte augmentation de solde et constitueront désormais dans les arsenaux des cadres fixes de surveillants." 24 In the early twentieth century the state began to pay foremen by the month instead of by the day like workers. "L'élévation [. . . ] des surveillants de travaux au-dessus de la condition inférieure qu'ils avaient pendant longtemps occupés, a créé dans les arsenaux une sorte d'aristocratie ouvrière". ${ }^{25}$

The introduction of task-rates altered the foreman's position in the work process. Auguste Gougeard, one-time Minister of the Navy, had lamented in the 1880 's the disruption of the existing system of labor relations that task-rates would bring.

21 "Commission chargée d'étudier les détails d'application du décret du 21 juin 1900 sur le personnel ouvrier" (August 1901), ibid.

22 DCN Rochefort, "Note sur les primes à la production et le travail à la tâche".

23 DCN Rochefort, 1891, AM 6 DD 1285 5611; DCN Lorient, 1898, AM 6 DD 1472 7511; “Commission chargée d'étudier les détails d'application" (August 1901), and DCN Cherbourg, "Note au sujet du travail à la tâche", 16 July 1902, both AM 6 DD 15197904.

${ }^{24}$ Fonlupt-Espéraber, Etude historique et critique, p. 90.

25 Mathias, Nos Directions de travaux, op. cit., p. 9. 
Il ne faut pas perdre de vue que, dès que l'on emploie d'une manière habituelle le travail à la tâche, les surveillants ne peuvent plus, à aucun titre, faire partie du personnel travaillant. [ . . ] L'emploi du travail à la tâche exclut presque complètement la communauté d'origine entre le personnel et le personnel surveillant. ${ }^{26}$

With task-rates, foremen experienced a new tension in their jobs between the technical supervisor's active participation in the production process through the guidance he gave to those under his command, and the administrator's concern with the finished product. One foreman explained shortly before the war:

Et pourtant jusqu'ici [le travail à la tâche] ne règne que dans des compagnies où le rôle technique des chefs est très, très restreint, ce qui lui permet de consacrer du temps à cette besogne de contrôle. Mais lorsqu'on en viendra à assujettir aux mêmes règles les spécialités où la présence du chef est nécessaire à tout instant pour inspirer, guider, vérifier l'exactitude du tracé, il sera alors impossible à l'agent technique de remplir ses fonctions de contrôleur en qualité sans négliger le contrôle de la justesse, de l'exactitude du travail. ${ }^{27}$

However, changes in the foreman's status and work responsibilities did not automatically create the new workplace atmosphere necessary to implement task-rates. In the largely mono-industrial port towns workers under the foreman's command were often his neighbors and relatives. These community ties and the traditional opposition of civilian and naval personnel worked to undercut efforts to strengthen hierarchical management at the lower levels. While some foremen who disciplined workers or set rates were harassed in town, ${ }^{28}$ others used their intermediary status to their own advantage. The director of naval construction at Cherbourg remarked in 1909 that as long as chefs ouvriers, workers who occasionally acted as supervisors, and foremen continued to live "tous au milieu des ouvriers, quelques-uns ménagent la chèvre et le choux, le directeur et les ouvriers." 29 The foreman's ambigious position fueled shipyard workers' complaints about wages based on production incentives. Task-rates, in themselves arbitrary because they could not be applied equitably to many jobs in the shipyards, increased the arbitrary powers of the foremen who monitored them.

26 A. Gougeard, Les Arsenaux de la Marine (2 vols; Paris, 1882), II, pp. 247-48.

${ }^{27}$ Fonlupt-Espéraber, Etude historique et critique, p. 125.

28 "La propagande antimilitariste et révolutionnaire dans les Arsenaux de la Marine de 1899 à octobre 1911", Archives Nationales (hereafter AN) F 713637.

${ }^{29}$ DCN Cherbourg, 1 May 1909, in Annales de la Chambre des Députés. Documents parlementaires, LXXVII, p. 916. 
The shipyard workers' union rejected payment based on criteria other than job classification and seniority, not only because such systems allowed the supervisory personnel too much leeway, but also because they did not take into account the effects of the debilitating working conditions in the shipyards. As navy doctors had attested in the Archives de la Médecine Navale since the Second Empire, the shipyards were notorious breeding grounds for tuberculosis. Workers opposed pay based on productivity because the added exertion it demanded would increase their risk of contracting tuberculosis and would force tubercular workers to retire earlier. However, navy doctors identified infected workers as sources of contagion and saw no reason to promote a system of fixed daily wages that would allow them to remain at work. Shipyard workers centered their attention on working conditions and attacked task-rates, which they viewed not as a means by which the worker could transcend his working situation, but as a system that would mire him more deeply in it. ${ }^{30}$ There was a clear contradiction between payment at piece-rates and the promise of lifetime employment. Incentive pay, especially when unaccompanied by other elements of managerial reform, proved an inadequate means to change the labor-force.

\section{Institutionalizing workers' representation}

Workers in heavy industry throughout France opposed rates based on production. What made the situation in the naval shipyards different was the direct intervention of the republican state. For naval shipyard workers the relationship between workplace life and politics was less problematic than for most industrial workers. Shipyard workers could extend their shopfloor struggles directly into the political realm by voting for candidates who would support their point of view in the legislature. In 1902 the deputy Paul Guiyesse, an active social reformer from Lorient, pushed a resolution through the Chamber of Deputies which halted payment by task-rates in the naval shipyards. Although this legislative solution lasted only a few years and was never fully implemented, it spurred the development of a series of efforts to reform labor management rarely encountered in the private sector before the war: the eight-hour day, consultation with unions, the team bonus (prime d'équipe) and worker participation in mixed committees (commissions mixtes).

Each of these four approaches was based on a different conception of the relation of the republican state to the worker. The across-the-board reduc-

30 "Commission chargée de l'étude des mesures à prendre à l'égard des marins et ouvriers tuberculeux. Rapport”, 29 August 1911, AM 6 DD 15267934. 
tion in the length of the working day involved a self-imposed limitation of the state's power with respect to the individual; state support of unions embodied a quasi-Durkheimian view of the state's relationship with corporate bodies in society; the team bonus recalled mid-nineteenth-century republican conceptions of artisanal work groups; the mixed commission provided a form of industrial democracy with clear roots in the judicial system and elected assemblies. What characterized each strategy was the idea that task-rates alone were an insufficient and potentially unjust means of motivating workers in the relatively closed labor market of the shipyards in which workers accepted low pay in exchange for the promise of a pension. Instead, the state as employer would receive better co-operation in exchange for some limitation of its power over the labor-force. The eighthour day and consultation with the union are most associated with Radical Camille Pelletan's tenure as Minister of the Navy in the cabinet of Radical Emile Combes (1902-05); the team bonus and mixed commissions provided alternatives to Pelletan's system and spanned several pre-war Ministries. Although mixed commissions were introduced before Pelletan's Ministry, they blossomed under succeeding administrations and are best examined after Pelletan's program.

As Minister, Pelletan took the most far-reaching steps toward satisfying the shipyard workers' grievances. In 1902-03 he acted directly to limit the ravages of tuberculosis by instituting the eight-hour day in all shipyards. The effect of this decree was enhanced by the passage in 1902 of Guiyesse's legislation forbidding task-rates in the shipyards. Pelletan also officially recognized the shipyard workers' union. His predecessor Lanessan had given de facto approval to the unions which had sprung up in the 1890's, but Pelletan went a step further by suggesting that co-operation between the Ministry and the unions in the name of the common goal of national defense was the way for the state to manage labor. Pelletan told a workers' banquet held to honor him at Toulon in 1904:

Nos relations ne sont pas celles d'un patron ordinaire avec ses ouvriers. Il faut au patron son dividende, un intérêt, de même que les ouvriers défendent leur morceau de pain. Moi, ce que je vous demanderais, si j'avais à exiger de vous plus que vous ne faites, ce ne serait pas un dividende, ce serait l'existence même de la défense nationale dont je suis le serviteur comme vous (Applaudissements). ${ }^{31}$

Although the union only came close to enrolling a majority of workers at the turn of the century, it enjoyed broad support from workers during the

31 L'Emancipateur, 1-15 September 1904. 
following decade. ${ }^{32}$ Since 1900 a union delegation had met with the Minister (and later the Budget Commission of the Chamber) after the union's national congress. Pelletan took advantage of these and other meetings with union leaders to build an informal alliance with the workers against the naval officers, who resented his administration. ${ }^{33}$ His chef de cabinet told a union congress that, since the Minister could not know everything that went on at the shipyards, he counted on the union to keep him informed. ${ }^{34}$ Beginning with Pelletan's Ministry, union delegates continued to be paid their daily wages while consulting with the Minister and attending the annual national union congress. ${ }^{35}$

A high-ranking official in the Ministry during Pelletan's tenure published a book with the official approval of the Ministry in which he argued that a strong and well-organized union would be the key to developing a laborforce free from the work habits of the past. ${ }^{36}$ In fact, Pelletan's special relationship with the union suggested a form of corporate syndicalism in which the Ministry and the unions would go beyond the elimination of taskrates to control the powers of intermediary supervisors. What limited Pelletan from going further in co-operating with the unions was the fear that "the reactionary party" would use this to bring down his Ministry and attack the right of state workers to unionize: in 1903, for instance, when working out an arrangement with the union on disciplinary measures for Toulon workers, he asked the union leadership to be discrete about the accord in order to avoid drawing conservatives' attention to it. ${ }^{37}$ Conflicts arose between Pelletan and the union, however, over the Minister's insistence that naval shipyard workers did not have the right to back up their demands by striking. ${ }^{38}$ After Pelletan left office in 1905, his successors proclaimed the failure of his model of industrial relations, although they sought to remain on good terms with the union. Extensive use of overtime turned the eight-hour day into a means of allowing the shipyards greater

32 "La propagande antimilitariste et révolutionnaire dans les Arsenaux de la Marine de 1899 à octobre 1911”.

${ }_{33}$ Commissaire spécial of Lorient to Prefect of Morbihan, 2 July 1904, AN F 713638 . See also Ribeyrol, De la Condition économique et juridique, op. cit., pp. 189-90.

34 Fédération nationale des travailleurs réunis de la Marine de l'état, 4 me Congrès tenu à Paris les 25, 26, 27, 28, 29, 30 juin, 1er, 2, 3 et 4 juillet 1903 . Compte-rendu des procèsverbaux et revendications adoptées (Toulon, 1905), p. 8.

35 Bureau administratif, Direction Centrale des Constructions Navales, "Note sur les reformes réalisées depuis 1900 en ce qui concerne le personnel ouvrier de la Marine", 6 April 1906, AM 6 DD 15738278.

36 Dagnaud, La Condition des ouvriers, pp. 178-79.

37 Fédération nationale, 4me Congrès, op. cit., pp. 7, 13.

38 "La Fédération nationale des travailleurs de la Marine de l'Etat" (circa 1908), AN F 7 13637. 
flexibility in allocating their fixed supply of labor, while supplementing the workers' low wages.

Shortly after Pelletan's departure, the Senate asked the Radical Minister Gaston Thomson to re-introduce some form of task-rates. For the Radical Emile Chautemps, a leading critic of the shipyard workers in the Senate, task-rates would develop individualism and reveal the hollowness of Pelletan's plans: the worker would no longer feel the need "de s'affilier à un syndicat et de se plier à une discipline souvent lourde". ${ }^{39}$ The Ministry responded to workers' grievances over task-rates by placing constraints on their application and by experimenting with the division of bonuses equally among all workers in a production group (primes d'équipe). In 1908 the Ministry limited to twenty-five per cent or to two hours per day the amount by which an individual worker was allowed to beat a rate. This appeased workers by cutting down on the competitiveness that could cause rates to drop, while reducing the individual's incentive to overwork or to work carelessly. ${ }^{40}$ Two years earlier the Ministry had implemented the prime d'équipe with some success in the manufacture of torpedos at Toulon. ${ }^{41}$ Workers received all of the "profit" they generated under this system rather than splitting it with the shipyard as they had with the prime horaire..$^{42}$ The shipyard paid the same amount for labor, but got it done more quickly.

Yet task-rates continued to concern only a minority of workers. In 1911 nine per cent of the shipyard workers were paid by task-rates, but because of minimum salaries by class and seniority, production bonuses accounted for only one-quarter of one percent of wages ${ }^{43}$ No modified form of taskrates satisfied the government's desire to re-cast labor relations in the naval shipyards. Rather than depending on union co-operation, Ministers before and after Pelletan placed their faith in mixed committees of workers and supervisors to regulate hiring, advancement and discipline. The decision to make workers privy to such managerial decisions went well beyond the rationale for the contemporary anti-union institutions set up in private industry, like the shop delegates at Le Creusot. ${ }^{44}$ The aim of the mixed

39 Cited by Fonlupt-Espéraber, Etude historique et critique, p. 134.

40 DCN Brest, 26 April 1909, in Annales de la Chambre des Députés, LXXVII, pp. 89091; Krebs, Les Arsenaux et établissements de la marine, op. cit., p. 47.

41 DCN Toulon, 1907, AM 6 DD 1633 8836; L'Emancipateur, 1-15 October 1907 and 15-31 July 1910; Royer-Collard, Les Ouvriers des arsenaux, op. cit., pp. 50-51.

${ }^{42}$ DCN Rochefort, 27 June 1902, AM 6 DD 1519 7904; Ribeyrol, De la Condition économique et juridique, p. 152.

${ }_{43}$ Krebs, Les Arsenaux et établissements de la marine, pp. 44-45.

44 See Etablissements Schneider, Economie sociale (Paris, 1912). 
committees was not to bring workers into management, however, but to find a way to reward merit while satisfying workers who complained of favoritism on the part of their supervisors. The state, as the embodiment of the national collectivity, had to be more careful than any private firm not to let workers impede its action. For the same reason, favoritism could have no place in the relations between the state and individual citizens, whether or not they were employees.

\section{Institutionalizing workers' representation, 2}

The reforms of 1892 had established minimum and maximum wages for six categories of workers, but had left the setting of wages to the head engineer (chef de service). This gave rise to widespread and, according to shipyard engineers, justified complaints. ${ }^{45}$

En principe, [one explained] c'était au chef de service qu'incombait le soin de fixer le taux des salaires et de prononcer les avancements. En fait, c'était toujours l'avis des contremaîtres qui décidait du choix dans les deux cas, et ceux-ci pouvaient d'autant plus facilement subir l'influence des relations et des camaraderies, qu'ils échappaient à toute responsabilité..$^{46}$

In 1900 the Minister Lanessan took the first steps to rectify this situation. He instituted two mixed committees. The commission de l'admission, composed of a chef d'atelier or a foreman, and two chefs ouvriers, administered tests to prospective workers and used the results to decide who should be hired and what their initial wages should be. Lanessan also established commissions d'avancement in each atelier to distribute a fixed sum of credits annually among the best workers. These committees were modeled after a short-lived institution of the Second Republic and were composed of three supervisors chosen by turns and two chefs ouvriers, selected at random in each atelier. In order to limit the possibility for favoritism to come into play, the director had the chefs ouvriers changed frequently.

The commissions d'avancement allocated primes de capacité, which were added to the worker's daily wage. While years spent at the shipyard remained the fundamental determinant of rank, and therefore of pay, the accumulation of primes de capacité led to quicker promotion and therefore raised an individual's pay. The chef de service could accept or reject these

45 Krebs, Les Arsenaux et établissements de la marine, pp. 19-20; Ch. Ferrand, Programme naval. Etudes maritimes (Paris, 1908), pp. 127-28.

${ }_{46}$ Bureau administratif, Direction Centrale des Constructions Navales, "Note sur les reformes réalisées depuis $1900 "$ ". 
recommendations, but could promote workers on his own initiative only in exceptional circumstances. Lanessan explained:

J'estime que cette mesure, loin de porter atteinte au prestige des chefs de service, ne fera que consolider leur autorité morale, en les mettant à l'abri des recriminations incessantes que provoque dans le personnel ouvrier de nos ports l'application du système actuel d'avancement et d'augmentation de salaire. ${ }^{47}$

A chef de service could afford to loose a portion of his nominal power if he could counter charges of arbitrariness and favoritism on the part of his foremen. The mixed committees checked the foreman's power to act in his own interests against either those of the individual worker, or in aiding a worker, against those of the shipyard as a whole. The committees protected workers by bringing determination of the discretionary portion of wages into the open. Yet the union repudiated the committees for the very reason that they seemed to give legitimacy to some form of payment by "merit". The union's national council called the primes de capacité "primes au favoritisme".

Sous un regime démocratique, un Ministre réellement reformateur doit employer toute son activité et son énergie à faire disparaître cet esprit de favoritisme, et empêcher les appétits de certains bas fonctionnaires qui se considèrent comme des petits roitelets dans les ateliers d'accaparer par des moyens inavouables, une partie des salaires de leurs subordonnés en acceptant des pots-de-vin de toute nature, car de cette situation tous les ouvriers souffrent. ${ }^{48}$

The union flatly rejected these bonuses as a subversion of its goal of equal pay for all workers with the same job and seniority. As part of his policy of building bonds with the union, Pelletan reduced primes de capacité during his tenure as Minister.

Pelletan's successors were more skeptical of co-operation with the union and asserted their faith in the commissions d'avancement. Reforms in the duties and composition of the commissions before the war did not affect their goal of curbing the foreman's individual prerogatives in order both to protect the individual worker from the capriciousness of his immediate supervisors, and to strengthen the relative power of the upper echelons of management in the shipyards. After discussions with the union, the Minis-

47 Marine nationale, Réglementation du personnel ouvrier des arsenaux et établissements de la Marine et commentaires de décret du 21 juin 1900 portant réorganisation de ce personnel (Paris, 1902).

48 L'Emancipateur, 15 November 1903. At least one chief naval engineer strongly agreed that advancement by merit masked favoritism. Ferrand, Programme naval, op. cit., pp. 130-31. 
ter promulgated a decree in 1907 which replaced the primes de capacité with majorations d'ancienneté of from three to twelve months. ${ }^{49}$ The commission could reward individual workers with additional fictional months of tenure. These were cumulative, and when combined with the amount of time actually spent on the job led to advancement in rank at a faster rate than simple tenure. This new system ended the situation in which a worker who was on the verge of obtaining a prime de capacité from one commission saw his chances dashed when the commission disbanded and a new one was created.

Le présent décret conserve toujours une part importante à l'ancienneté, mais, pour ce qui est du choix, il ne laisse plus à une seule commission le soin de décider de l'avancement d'un ouvrier; c'est la totalisation des opinions émises par plusieurs commissions successives qui crée cet avancement, et comme la plupart des membres de ces commissions changent tous les ans, les craintes de favoritisme sont par cela même écartées. En outre, chaque ouvrier, sachant chaque année, s'il a été reconnu digne, et dans quelle proportion, d'avancer au choix, est mieux à même de se rendre compte de l'effort qu'il doit faire dans l'avenir pour mériter un avancement plus rapide. ${ }^{50}$

In a republican system of management the worker was not only to be protected from the whims of his individual supervisors, but was to know exactly where he stood with respect to advancement at any time. While the followers of $F$. W. Taylor proclaimed the need to measure accurately the effort undertaken by a worker in order to determine his pay, the naval shipyards of the Third Republic sought to provide a way for the individual worker himself to gauge the amount of effort necessary to raise his wages and rank.

The decree of 1907 added two workers or chefs ouvriers elected by secret ballot to each commission d'avancement. This gave the combination of workers and chefs ouvriers a majority. In 1912 the Minister Théophile Delcassé reduced membership on the commission to five members: the two elected workers or chefs ouvriers, a foreman chosen by rotation from the atelier, the chef d'atelier, and the engineer in charge of the atelier. By removing the two chefs ouvriers from the commission, the Minister placed the workers as a general category in a minority. This affected the balance of power on the commissions, but not the overall goal of overseeing the

49 The union's general secretary was especially pleased by the union's opportunity to participate in the drafting of the new regulations: "Pour la première fois, après près de 48 ans de République, les organisations ouvrières sont admises à discuter les règlements qu'elles seront appelées à subir et à présenter l'introduction des modifications qu'elles désiraient voir introduire dans ces règlements." L'Emancipateur, 1-15 March 1907, p. 1. so Ibid., 16-30 June 1907. 
actions of individual supervisory personnel. The change revealed the fall in status of the hybrid chef ouvrier, who possessed the liabilities of the foreman in terms of social origins and type of power exercised. ${ }^{51}$

Like advancement, discipline was a source of friction between shipyard workers and their supervisors. Workers argued that the military style of discipline, not the system of advancement, hindered workers' productivity. Frès, a union leader from Toulon, complained in 1904 that the naval authorities turned the fixed daily wage into a means to punish workers.

[L]a réglementation militariste à laquelle nous sommes asservis nous procure de nombreux mécomptes qui n'existent pas dans l'industrie. Ainsi, pour cinq minutes de retard, nous perdons une heure de notre salaire, pour dix minutes deux heures, et ces rabais forcés nous poussent à des absences dont la moyenne pour tous les ouvriers des arsenaux doit s'élever sans exagération à dix jours par an. ${ }^{52}$

Ministers of the Navy reformed aspects of the administration of discipline on several occasions before the war. In the late nineteenth century gendarmes played an important role in supervision. The director of naval construction at Cherbourg reported in the 1890's that gendarmes were "plus indépendants, moins paternels" than foremen and frequently punished workers whom they saw idle. ${ }^{53}$ Until 1900 both gendarmes and supervisors had the right to imprison workers for disobedience on the job. In 1900 Lanessan withdrew this prerogative. Seven years later Minister Thomson decided that workers accused of serious breaches of discipline should be brought before a conseil de discipline, a tribunal composed of one officer, one chef d'atelier, one foreman, one chef ouvrier and one worker. The Ministry soon found that

L'officier et l'agent technique en chef [le chef d'atelier] représentaient le personnel dirigeant; mais le simple agent technique [foreman] qui, à première vue, pourrait être considéré comme appartenant au même personnel, participe beaucoup plus aux conditions générales du personnel ouvrier par

51 For the chefs ouvriers' complaints about their decline in status and difficulties in carrying out their supervisory tasks, see ibid., 16-31 July and 1-15 October 1905.

52 Ibid., 16-31 March 1904. In demonstrating the effects of these lost days on the shipyard workers' wages, Frès revealed the importance of guaranteed employment at the shipyards. He argued that a shipyard worker earned $F 3.46$ per day for three hundred days of work. After taking into account the ten lost days, his average income was $F 2.77$ for each of the 365 days of the year. The same worker in private industry earned F 5.20 per day, but could only get work an average of 210 days per year. He earned an average of F 3.01 for each of the 365 days of the year. With or without the losses from military discipline, the worker's annual wage in the shipyards and in private industry was much closer than a comparison of their daily wages would lead one to believe.

53 Assemblée Nationale, Commission extraparlementaire de la Marine, Délégations (6 vols; Paris, 1897), II, p. 105. 
ses origines et ses attaches; ainsi était-ce presque toujours pour l'ouvrier qu'il votait.

In 1912 the Minister Delcassé rectified this situation by replacing the foreman on the conseil de discipline with a second naval officer. Whereas the commission d'avancement checked the individual foreman's powers without eliminating foremen as a group from the deliberation process, the conseil de discipline after 1912 flatly denied foremen a role in judging matters brought before it. The new composition of the conseil highlighted the difference between the shipyards and "l'industrie privée où c'est généralement le contremaître qui congédie les ouvriers dont il a à se plaindre, ceux-ci n'ayant le plus souvent qu'un simple recours devant le directeur".${ }^{54}$ Through the conseils de discipline the Republic took a further step to banish the favoritism that was thought to characterize the foreman by turning over part of his power to punish to a judicial committee. Writing in 1908, one naval chief engineer commented that the foremen no longer exercised any disciplinary function; they were solely technical agents. Even in this realm foremen turned over some of their former functions to draftsmen who prepared jobs for workers. ${ }^{55}$ Foremen lost power throughout large industry in the late nineteenth century. However, naval shipyard managers went further than those in the private sector in reducing the foreman's authority in order to legitimate and strengthen their own.

The sensitivity of moderate republicans to charges of arbitrary and unjust treatment in the years after the Dreyfus Affair - as opposed, for example, to a concern for democratic procedures in organizing work - ironically led the Republic to shift the exercise of power to men whose status as officers and engineers would presumably make them immune from base favoritism in dealing with individual workers. Yet these officers saw their ability to hire, promote and punish restricted, in theory at least, by the commissions set up before the war. In practical terms, however, the officers profited from the concomitant rise in the foreman's official status and devaluation of his power on the job.

The workers experienced these changes quite differently. While the various commissions protected individual workers from flagrantly unjust treatment by their immediate superiors, workers lost informal means of exercising power in the years before the war as a result of the re-definition of the status and rights of the foreman. In the nineteenth century workers had been able to exert pressure on foremen because the foreman's job and mode of pay had made him more the primus inter pares than the loyal

54 Krebs, Les Arsenaux et établissements de la marine, pp. 23-26.

55 Ferrand, Programme naval, pp. 132-37. 
representative of management at the workplace. Equally important, the foreman's membership in the community composed of the shipyard workers and their families, though it encouraged individual cases of favoritism, also ensured the foreman's general sympathy to the workers' interests. The re-organization of the shipyards before the war officially differentiated the foremen from the workers at work, while limiting the foreman's power to act on his own initiative. The effect of these reforms was to separate the foreman from the worker at the workplace, while restricting the effectiveness of community pressure on the foreman off the job. ${ }^{56}$

The managerial systems introduced in the naval shipyards in the two decades before World War I were an effort to find a form of industrial administration compatible with both the shipyards' responsibility for national defense and its position as an institution of the Third Republic. Neither payment by individual piece-rates nor dependence on the authority of foremen satisfied these requirements. The piece-rate opened the door for favoritism, surmenage, and divisive competition between individual workers. Pelletan responded with the eight-hour day, which placed limits on the daily exploitation experienced by the worker. His successors preferred team bonuses, which rewarded co-operation in work groups without encouraging overwork (because there was a limit on compensation for beating a rate). Dealing with the worker as an individual or in a small group was not sufficient, however. Authorities needed some way to treat workers as a whole. Pelletan pursued the idea of co-operation with unions. Other Ministers adapted models from the judicial and electoral systems of republican France to commissions which handled issues of rank, pay and discipline. Recent work on the implementation of scientific management has shown that it proceeded not through a uniform de-skilling of labor, but through tactical alliances between elements within management and the labor-force. ${ }^{57}$ In the case of the shipyards, one can discern a related

56 For examples of the effectiveness of workers' harrassment of foremen, see Préfet maritime Lorient to Ministre de la Marine, 23 February 1912, AM 6 DD 1 497. In 1912 the shipyards began to intervene directly to limit attacks on supervisory personnel off the job. Krebs, Les Arsenaux et établissements de la marine, p. 30 explains: "Jusqu'au décret du 12 mai 1912, les ouvriers pouvaient en dehors de l'arsenal, se livrer à l'égard de leurs supérieurs aux menaces, aux outrages et aux violences qu'il leur plaisait sans avoir à craindre aucune peine disciplinaire. Tout ce que pouvait faire le supérieur ainsi traité, était de s'adresser à la justice civile, et il devait continuer l'exercice de ses fonctions et commander même les ouvriers qui l'avaient outragé, menacé, comme si rien ne s'était passé. Cette situation déplorable a heureusement cessé; le préfet maritime, après avoir pris l'avis du conseil de discipline peut prononcer le congédiement contre tout ouvrier qui se sera rendu coupable des actes que nous venons d'indiquer."

${ }^{77}$ D. Stark, "Class Struggle and the Transformation of the Labor Process", in: Theory and Society, IX (1980), pp. 89-130. 
phenomenon: the introduction of some form of payment by performance and (as shall be shown) a somewhat more flexible hiring policy generated new ideological and organizational developments which strengthened certain elements of workers' position at the expense of others.

\section{"Industrialization" of the shipyards}

In the early twentieth century naval officers assumed greater control over labor management in the shipyards. Workers were powerless to influence these distant figures in the way they had been able to influence their foremen. They strongly resented working directly under the naval officers' command on shipboard. ${ }^{58}$ The frustration born of tensions between workers and officers fueled impressive demonstrations of antimilitarism in the shipyards before the war. As of 1911, eighty-five shipyard workers, including sixty-four at Brest, had been placed on the Carnet $B{ }^{59}$ This antimilitarism perplexed many outside observers, who confused it with pacifism. Far from seeking to destroy the basis of their jobs, the shipyard workers lobbied strongly against the granting of contracts for warships to private companies: this dependence on the state generally assured the triumph of reformist politics in naval shipyard towns. ${ }^{60}$ Antimilitarism must be analyzed within a particular context.

Antimilitarist syndicalists in private industry opposed the army primarily for its role in putting down strikes; antimilitarist shipyard workers generalized their attack on the military discipline to which they were subject. ${ }^{61}$ In 1905 workers at Lorient and Brest strongly criticized the maritime prefect's punishment of workers for Speeches they had made outside of the workplace: they charged that this was a reversion to the Second Empire that was contrary to the nature of the Republic. ${ }^{62}$ In fact,

58 See, for example, the dossier on events at Cherbourg in November-December 1907 , AM 6 DD 1497.

59 "La propagande antimilitariste et révolutionnaire dans les Arsenaux de la marine de 1899 à octobre 1911"; Commissaire spécial of Brest, "Historique", AN F 7 13639. On antimilitarism at Brest, see G. Baal, "Victor Pengam et l'évolution du syndicalisme révolutionnaire à Brest (1904-1914)”, in: Le Mouvement Social, No 82 (1973), pp. 55-82. ${ }^{60} \mathrm{~J}$. Quellien, "Un Milieu réformiste: syndicalisme et réformisme à Cherbourg à la 'Belle Epoque”, in: Le Mouvement Social, No 127 (1984), pp. 65-88.

61 In 1909 the union's comité fédéral evoked the relationship of military discipline and occupational hazards: "L'antimilitarisme est né du militarisme moderne comme la tuberculose est née de la misère, et ce n'est pas remédier à un mal que d'en punir ceux qui en souffrent et s'en plaignent, c'est l'aggraver, au contraire, c'est exacerber le sentiment de rancune qui germe dans la classe ouvrière contre cette armée dévoyée dans un rôle de police intérieure et que l'on place implacable et meurtrière au travers de ses espoirs." L'Emancipateur, 1-15 September 1909.

62 Prefect of Morbihan to Ministre de l'Intérieur, 26 October 1905, AM 6 DD 1499. 
because the Chamber, rather than the Minister, set the overall wage package, strikes and demonstrations at the shipyards were generally over the exercise of civil liberties, not over rates. Workers' protests clearly revealed one limitation of "republican" management of military establishments.

It was in this context that Ministers began to take steps toward the "industrialization" of the naval shipyards. "Industrialization" did not refer primarily to a technological change, but instead to operation of the shipyards along the lines of private industry. This broke with the prevailing view of the shipyards, articulated by the central director of naval construction in 1903.

Les Arsenaux et Etablissements de la Marine ne pouvant à aucun titre être envisagés comme des exploitations industrielles, les ouvriers qui y sont employés sont des sortes de fonctionnaires et peuvent, dans ces conditions, bénéficier d'un ensemble d'avantages que ne pourrait leur offrir aucune entreprise industrielle. ${ }^{63}$

While maintaining its commitment to reduce favoritism and arbitrariness, the state went about re-defining the terms of employment for shipyard workers. Seeking flexibility in the size of the labor-force, the shipyards before the war began to use overtime on a regular basis, to grant two-week vacations and to hire temporary workers (auxiliaires), who could be dismissed at any time. The shipyards offered the auxiliaires the going rate in the region, which was often higher than that paid to permanent shipyard workers with ten or fifteen years seniority. ${ }^{64}$ This disparity rendered explicit the exchange of wages for job security and retirement benefits that naval shipyard workers continued to make on the eve of the war.

The war undermined the position of the immatricule and dealt a death blow to the existing system of labor relations. After the first months of hostilities the shipyards began manufacturing munitions and expanded rapidly by taking on auxiliaires. Only one-eighth of the personnel in 1910, the auxiliaires constituted the majority by 1918 . The war revealed that immatriculés were no longer necessary. The length of the war gave the state the opportunity to re-organize work in the shipyards. More importantly, the state's success in the forced recruitment and employment of nonpermanent labor revealed the possibility of replacing the existing system, premised on the ancien régime practice of drawing on a regional labor

63 Directeur central des Constructions navales to Ministre de la Marine, 23 January 1903 , AM 6 DD 15197904.

${ }_{64}$ To soften the blow of introducing auxiliaires, the Minister decreed that recruitment of permanent workers in the future would be almost entirely through apprenticeship and that preference would be given to the children of shipyard workers. 
market and the Third Republic's concern over the location of shipyards in areas without alternative sources of industrial labor. The war clearly displayed the state's ability to constitute the needed labor-force in periods of national emergency.

From the beginning of the war the different treatment accorded immatriculés and auxiliaires created tensions. ${ }^{65}$ The auxiliaires lacked the immatriculés' guarantee of lifetime employment and were primarily interested in obtaining higher wages and escaping military discipline. The auxiliaires' concerns influenced the union's comité fédéral to come out in favor of "industrialization" of the shipyards as a vehicle for social change in the spring of 1918.

[Les militants] savent que la condition des travailleurs de la Marine, par leur statut, par la mentalité générale de leur organisation, est plus que toute autre, d'un âge périmé. Les circonstances nous paraissent exceptionnelles pour que nous coupions les ponts avec le passé et que nous allions résolument à l'avenir.

Le cadre des immatriculés, inspiré d'un véritable caporalisme, a une rigidité étouffante. Les ouvriers y ont pris une âme servile, sans initiative et sans enthousiasme, et toute la petite hiérarchie s'est modelée à l'adjudant, et tellement que nous l'avons vue lancée toutes ces dernières années à la seule revendication du bouton, de l'ancre et de l'épée. ${ }^{66}$

The union came to feel that its efforts before the war to insulate pay and advancement from production had undercut the basis of corporate and class solidarity. It looked to "industrialization" to change the terms of managerial discourse from the rights of the individual worker to the collective interests of workers, as expressed by their union. In making this decision, the shipyard workers' union participated in a general movement within the CGT toward co-operation with the state which had its roots in the years before 1914 and blossomed during the Socialist Albert Thomas's wartime tenure as Minister of Armaments. The militarization of labor in the private sector during the war had the long-term effect of reducing the difference between the management of labor in the shipyards and in private industry.

In 1920-21 the Minister introduced a number of reforms to streamline the shipyards along "industrial" lines. ${ }^{67}$ The argument was made that the real ${ }^{65}$ Commission de la Marine de Guerre, "Conclusions générales aux rapports des $2 e$ et $3 e$ Sous-Commissions approuvés par la réunion de la Commission le 30 juillet 1915", AN C 7531.

${ }^{66}$ L'Emancipateur, 15 April 1918 (quoted); L. Jouhaux, "La réforme qui s'impose", in: L'Heure, 11 September 1918.

67 See H. Fayol, "L'Industrialisation de l'Etat", in: Bulletin de la Société de l'Industrie Minérale, Fifth Series, XV (1919), pp. 237-74; S. Rials, Administration et organisation 1910-1930 (Paris, 1977). 
source of injustice, and of the worker's sensitivity to it, was his feeling that he was destined to spend his whole career in the shipyards, where low wages made guarantees of job security and advancement essential. The Ministerial decree of 1920 broke with this system by leaving open the possibility of re-integrating the shipyard worker into the private economic sector. In the naval shipyards, the system allowed for a somewhat more flexible policy of labor recruitment. All workers hired after 1920 would have the status of the old auxiliaires. The immatriculés retained their position, but when they retired, auxiliaires would take their places. Immatriculés with low productivity who met the conditions for retirement were made to do so. Non-immatriculés were given the opportunity to take six-month leaves to work in private industry. (It should be noted that, despite the assimilation of newly hired workers to their counterparts in private industry, most felt that the shipyard had the moral obligation to keep them on until retirement.) A mixed committee in each port, composed of five members of the upper management and three workers (but no foremen), set minimum and maximum wages based on regional wage scales. Under this new system the worker's profession and productivity counted more heavily than his seniority in the determination of wages. By offering competitive wages the shipyards were able to attract much-needed specialists, who otherwise would have remained in the private sector.

In making these changes, the Ministry never compromised its right, as the embodiment of the national collectivity, to set policy unilaterally. However, this did not prevent the shipyards from consulting on a frequent basis with the majority (CGT) union during the inter-war years. ${ }^{68}$ This reflected the adjustment from dependence on administrative and judicial structures to protect the rights of individual workers to a variant of corporatist labor relations. The status accorded the union combined with the demise of the privileged immatriculés to create a hybrid of the systems of labor management pursued before the war by Pelletan and by his successors.

\section{Conclusion}

In many respects labor policy in the naval shipyards between 1892 and 1920 resembled that in private industry. There was a general reduction in the authority of foremen in the decades before World War I. Certain institutional arrangements were made for labor and management to negotiate, i.e. the election of shopfloor delegates at Le Creusot after the strikes at the

68 See Appert, Les Améliorations récentes, passim, for a critique of the shipyard management's dealings with the unions. 
turn of the century to present workers' grievances to management, and to present management's point of view to workers. ${ }^{69}$ Peter Stearns has detected a move toward some forms of collective bargaining in French industry before the war (although not in many of the industries involved in the armaments business). ${ }^{70}$ Finally, private industry had its supporters in parliament who fought for contracts to provide business (and profits) for companies and employment for labor. Aristide Briand, deputy for the armaments center of Saint-Chamond, provides a clear example.

What differentiated the two sectors of the armaments business was the naval shipyards' role as an institution of the French military and of the Third Republic. F. W. Taylor touted his managerial system as a break with "military" styles of management. In the naval shipyards the Third Republic pursued the same goal by seeking to develop labor management that was consistent with the shipyard's military aims, but recognized the workers as citizens of the Republic. Management of labor in the naval shipyards gave republicans an opportunity to formulate a labor policy which went beyond general legislative actions, i.e. legalization of unions in 1884 , or administrative actions, i.e. intervention in the strikes of 1899-1900. In the shipyards the Republic sought to develop an institutional framework for incorporating labor into the industrial enterprise without fundamentally challenging managerial authority. This policy took two forms: 1) the creation of institutional means for the representation of labor in affairs which directly concerned it on the shopfloor, i.e. committees dealing with discipline and promotion, and in the broader economic realm, i.e. regular union consultation with the Minister of the Navy, and 2) the effort to decrease the personal powers of the foreman and to legitimate the authority of the upper echelons of the managerial hierarchy, even at the expense of a certain restriction of their powers. While the organization of production in the shipyards in terms of investment, mechanization and efficiency often struck observers as inferior to that of contemporary industrial firms, the government's experience managing labor in the shipyards through joint labor-management committees and through efforts to establish a working relationship with the union was an important precursor of successive government attempts to restructure labor relations in nationalized and private industry during World War I, the Popular Front and again after World War II. ${ }^{\text {I }}$

69 M. Massard, "Syndicalisme et milieu social (1900-1940)", in: Le Mouvement Social. No 99 (1977), p. 26.

${ }^{70}$ P. Stearns, "Against the Strike Threat: Employer Policy toward Labor Agitation in France, 1900-1914", in: Journal of Modern History, XL (1968), pp. 474-500.

71 The work in progress of Herrick Chapman of Stanford University on the French aircraft industry between 1936 and 1950 should be particularly illuminating in this regard. 